\title{
PENGARUH SMARTPHONE ADDICTION TERHADAP PERILAKU AGRESIF PADA REMAJA
}

\author{
Uswatun Hasanah, Udi Rosida Hijrianti, dan Iswinarti \\ Fakultas Psikologi Universitas Muhammadiyah Malang \\ Email: uswatunhasanahh90@gmail.com
}

\begin{abstract}
Abstrak
Penelitian ini bertujuan untuk mengetahui apakah smartphone addiction memiliki kontribusi dalam mempengaruhi munculnya perilaku agresif pada remaja. Responden dalam penelitian ini berjumlah 290 orang remaja yang berusia 15-20 tahun dengan lama penggunaan smartphone $>5$ jam dalam sehari, dengan teknik pengambilan data menggunakan insidental sampling. Pada penelitian inismartphone addiction sebagai variabel $X$ yang diukur menggunakan skala smartphone addictiondengan reliabilitas sebesar 0.943 . Sedangkan, perilaku agresif sebagai variabel $Y$ yang diukur menggunakan skala perilaku agresivitas dengan reliabilitas sebesar 0.779 . Analisa data pada penelitian ini menggunakan uji regresi linier sederhana. Hasil penelitian menunjukkan bahwa ada pengaruh positif dari smartphone addiction terhadap perilaku agresif pada remaja $(B=0.236)$ dengan taraf signifikan $p=0.000$ yang berarti terdapat pengaruh smartphone addiction terhadap perilaku agresif. Maka, dapat dijelaskan bahwa penggunaan smartphone secara berlebihan hingga menyebabkan adiksi dapat memicu munculnya perilaku agrresif pada remaja. Berdasarkan hasil penelitian, smartphone addiction memiliki kontribusi sebesar $14.2 \%$ terhadap perilaku agresif.
\end{abstract}

Kata Kunci : Smartphone addiction, perilaku agresif

\section{THE INFLUENCE OF SMARTPHONE ADDICTION TOWARDS AGGRESSIVE BEHAVIOR AMONG ADOLESCENTS}

\begin{abstract}
The research aimed to determine the influence of smartphone addiction has a contribution in influencing the emergence of aggressive behavior in adolescents. Respondents in this study were 290 adolescents aged 15-20 years with a duration of smartphone use $>5$ hours a day, with data collection techniques using incidental sampling. In this study,smartphone addiction as variable $X$ is measured using the smartphone addiction scalewith a reliability of 0.943. Meanwhile, aggressive behavior as variable $Y$ is measured using aggressiveness behavior scale with a reliability of 0.779. Data analysis in this study used a simple linear regression test. The results showed that there was a positive effect of smartphone addiction on aggressive behavior in adolescents $(B=0.236)$ with a significant level of $p=0.000$, which means that smartphone addiction has an effect on aggressive behavior. So, it can be explained that excessive use of smartphones that causes addiction can trigger aggressive behavior in adolescents. Based on the research results, smartphone addictioncontributed $14.2 \%$ to aggressive behavior.
\end{abstract}

Keywords : Smartphpone addiction, aggressive behavior

\section{Pendahuluan}

Perilaku agresif didefiniskan oleh Murray sebagai cara untuk melawan dengan kuat, untuk berkelahi, untuk melukai menyerang, dan untuk membunuh atau menghukum orang lain (Hutomo \& Ariati, 2017). Hal tersebut bisa merupakan perilaku untuk menyakiti orang baik secara fisik maupun psikologis. Atkinson (Hutomo \& Ariati, 2017) menyatakan bahwa agresi merupakan suatu reaksi 
emosional. Kemudian, Bandura (Susantyo, 2018) beranggapan bahwa perilaku agresif bukan sesuatu yang dibawa dari lahir, namun sesuatu yang dipelajari. Buss dan Perry (1992) mendefinisikan perilaku agresif adalah perilaku individu yang cenderung menyakiti orang lain, baik secara fisik ataupun psikis untuk mengekspresikan perasaan negatifnya (Dini \& Indrijati, 2014).

Perilaku agresif diartikan sebagai tindakan yang dimaksudkan untuk melukai atau menyakiti orang lain, baik fisik maupun psikis seseorang yang menimbulkan kerugian atau bahaya bagi orang lain (Siddiqah, 2010). Perilaku agresif terbagi menjadi dua, yaitu agresif fisik dan agresif verbal. Agresif fisik adalah suatu tindakan yang menimbulkan sakit secara fisik pada orang lain, sedangkan agresif verbal adalah bentuk komunikasi yang menimbulkan sakit secara psikis pada individu yang menerimanya (Syahadat, 2013).

Buss dan Perry (Palinoan, 2015) menyatakan bahwa terdapat empat macam dimensi dari agresi yaitu pertama, agresi fisik merupakan agresi yang melibatkan individu untuk melukai orang lain secara fisik seperti melakukan pemukulan ataupun menendang; kedua, agresi verbal merupakan agresi yang melibatkan individu untuk menyakiti orang lain melalui verbal seperti menghina, mengumpat, membentak atau mengejek; ketiga, kemarahan adalah berupa perasaan dan tidak mempunyai tujuan apapun seperti individu yang sedang marah dikarenakan sedang merasa tersinggung atau frustasi; keempat, kebencian merupakan salah satu sikap yang negatif dalam individu kepada orang lain dikarenakan penilaian oleh diri sendiri seperti curiga terhadap orang lain karena sikap orang lain.

Baron dan Byrne mengelompokkan penyebab timbulnya agresi menjadi tiga yaitu pertama, agresi sebagai perilaku bawaan; kedua, agresi yang berakibat dari sosial ialah teori yang dikembangkan Bandura yaitu bahwa individu berperilaku sosial berlandaskan hasil pengamatan, meniru, penghargaan serta hukuman; ketiga, agresi sebagai akibat ekspresi frustasi ialah teori yang dikemukakan oleh Mowver Sears dan tokoh lainnya menyatakan bahwa perilaku agresi disebabkan oleh faktor frustasi individu (Aziz \& Mangestuti, 2006). Guswani dan Kawuryan juga menyebutkan bawa faktor-faktor penyebab dari munculnya perilaku agresif adalah dari kematangan emosi individu, kontrol diri, religiusitas, serta kecerdasan emosi dan pengaruh media (Illahi, Neviyarni, Said,\& Ardi, 2018).

Remaja merupakan periode individu dengan gejolak yang diwarnai dengan konflik dan perubahan suasana hati (Santrock, 2011). Pada periode remaja ini akan labil, ia sedang berusaha untuk mencari jati dirinya dan mudah menerima informasi dari luar tanpa berpikir lebih lanjut terlebih dahulu. Ketidakmampuan remaja dalam mengelola informasi dengan benar serta menyesuaikan diri dengan lingkungannya menjadi salah satu hal yang mendukung perilaku agresif tersebut. Penyebab dari perilaku agresif bisadari berbagai faktor, misalnya adanya perasaan kurang diperhatikan, ada tertekan, memiliki pergaulan yang buruk, dan efek dari tayangan kekerasan di media masa (Restu,Yusri, \& Ardi, 2013).

Pola perilaku agresif pada remaja yang awalnya hanya agresi verbal atau perkelahian antar remaja lainnya saja, saat ini sudah semakin mengarah pada tindakan-tindakan yang tergolong sebagai tindakan kriminalitas seperti pencurian, pemerkosaan, penculikan, pengancaman pembunuhan bahkan pembunuhan (Badan Pusat Statistik, 2010). Fenomena perilaku agresif pada remaja saat ini seperti yang terjadi pada salah satu sekolah di Gunungkidul, seorang remaja mengancam guru dengan celurit lantaran ponselnya disita sehingga anak yang sudah merasa kecanduan dan tidak bisa tanpa ponsel tidak dapat mengelola emosi dengan baik dan memunculkan 
perilaku agresifnya (INews.id, 2019). Hal tersebut dapat termasuk pengancaman menggunakan senjata tajam dikarenakan kecanduan smartphone.

Zaman sekarang smartphone sudah diberikan dari usia dini. Hal tersebut disadari ataupun tidak akan membentuk kebiasaan terhadap anak. Pada tahun 2012, di Indonesia sebanyak $27 \%$ anak di usia balita dapat menggunakan smartphone, di tahun 2014, jumlahnya meningkat menjadi $73 \%$ bahkan $29 \%$ memiliki tablet pribadi pemberian orang tuanya (Wijanarko,2017). Orang tua terkadang menjadikan alasan kesibukan pekerjaan sebagai salah satu penyebab mereka memberikan smartphone di usia dini pada anak, hal yang berulang diberikan kepada anak bisa menyebabkan kecanduan atau adiksi terhadap hal tersebut. Harvard Health Publishing (Utami, 2019) mendefinisikan adiksi merupakan pengaruh yang akan bertahan lama dan kuat dengan tiga karakteristik yang khas, yaitu : kemauan yang kuat dalam menggunakan suatu objek, hilangnya kontrol untuk penggunaannya, dan akan selalu terlibat dengan objek tersebut tanpa memikirkan efek bahayanya. Adiksi bisa berbentuk pada kecanduan terhadap apapun, termasuk pada smartphone.

Menurut Kim definisi adiksi smartphone merupakan sebagai bentuk penggunaan dengan waktu yang berlebihan dan melibatkan diri sendiri secara mendalam pada suatu hal yang menjadi ketergantungan, sehingga hilangnya kontrol diri dan munculnya kecemasan psikologis (Cho, Kim, \& Park, 2017). Kwon, et al (2013) mengatakan istilah dari smartphone addiction yaitu perilaku kecanduan terhadap smartphone yang dapat mengakibatkanterjadinya masalah sosial terhadap individu.

Terdapat enam dimensi smartphone addiction (Kwon, et al, 2013) yaitu: 1) Daily-life disturbance merupakan suatu kehilangan pada pekerjaan yang telah terencana, mengalami kesulitan dalam berkonsentrasi, merasa pusing, kaburnya penglihatan, terasa nyeri pada pergelangan tangan atau belakang leher serta adanya gangguan tidur, serta lebih memahami bahwa smartphone adalah bagian penting dalam hidupnya dan menghabiskan waktu untuk menggunakan smartphone; 2) Positive anticipation merupakan gambaran bahwa menggunakan smartphone akan menimbulkan atau menciptakan perasaan gembira dan menyingkirkan stress dan akan merasa hampa jika tidak menggunakan smartphone; 3) Withdrawal merupakan individu yang memiliki perilaku tidak sabaran, memiliki kegelisahan dan tidak dapat memberi toleransi jika tidak menggunakansmartphone, akan terus memikirkan smartphone bahkan saat sedang tidak menggunakan smartphone dan akan merasa kesal ketika diganggu orang lain saat menggunakan smartphone; 4) Cyberspace-oriented relationship merupakan hubungan lebih eratseseorang dengan teman yang didapatkan dari penggunaan smartphone daripada hubungan dengan teman-teman yang berada di dunia nyata, yang mengakibatkan akan selalu memeriksa smartphone; 5) Overusemerupakan penggunaan smartphone yang tidak dapat dikendalikan, individu lebih memilih untuk melakukan penelusuran menggunakan smartphone daripada meminta bantuan orang lain, serta akan selalu menyiapkan pengisian daya smartphone; 6) Tolerance merupakan percobaan untuk mengontrol penggunaan smartphone namun selalu gagal dalam melakukannya.

Penggunaan smartphone yang apabila melebihi dari dalam waktu empat jam dalam sehari dapat mengakibatkan parahnya kecenderungan adiksi (Aljomaa, et al., 2016). National Information Society Agency South Korea (Kwon, Kim, Cho, \& Yang, 2013) menyebutkan bahwa prevalensi dari adiksi terhadap smartphone sekitar 8,4\%. Angka tersebut melebihi angka dari pravelensi terhadap perilaku adiksi internet. Penelitian yang berhubungan dengan adiksi smartphone lebih banyak 
dilakukan di negara yang merupakan penghasil darismartphone, sedangkan untuk negara pengguna smartphone masih cukup minim (Miura \& Rukmini, 2016).

Hasil penelitian yang dilakukan Demirci, Akgonul, dan Akpinar (2015) menyebutkan bahwa penggunaan smartphone secara berlebihan dapat menyebabkan depresi, kecemasan dan penurunan kualitas tidur atau gangguan tidur pada penggunanya. Sehingga dapat saja menciptakan perilaku menyimpang seperti perilaku agresif pada remaja. Lee dan Lee (2017) mengemukakan bahwa remaja akan rentan terpengaruh oleh smartphone sehingga menyebabkan rendah dalam prestasi dibidang akademik, memiliki hubungan sosial dengan keluarga tidak baik, dan merasa tidakpuas pada kehidupan sekolahnya. Hal tersebut sejalan dengan hasil penelitian yang dilakukan oleh Utami (2019), menyebutkan bahwa efek negatif dari adiksi smartphone dapat mempengaruhi aspek-aspek pada akademik remaja dari segi personalnya, seperti menurunnya prestasi akademik remaja.

Walaupun tidak semua tayangan yang ada didalam smartphone bersifat negatif namun pada jaman sekarang kebanyakan hal yang ditayangkan dan dipaparkan pada smartphone adalah hal-hal negatif yang sulit untuk disaring oleh remaja. Penelitian lainnya tentang pengaruh dari smartphone addiction, dilakukan oleh Lee, et al (2018) pengaruh adiksi smartphone adanya beberapa masalah perilaku dan emosi, hal tersebut berdasarkan pengakuan subjek remaja yakni mereka merasa memiliki masalah beban pikiran yang berlebihan, kesulitan untuk mengatur perhatian, timbulnya kecenderungan agresivitas, serta perilaku untuk merusak diri.

Berdasarkan pada penelitian-penelitian terdahulu di atas, disebutkan bahwa adiksi smartphone dapat mempengaruhi perilaku emosi penggunanya dan memiliki kecenderungan untuk berperilaku agresif. Pada penelitian ini, peneliti ingin menggunakan konteks lebih luas, tentang hal yang mempengaruhi perilaku agresif jika disangkutkan dengan adiksi smartphone. Selain itu, perbedaannya juga terletak pada beberapa penelitian terdahulu kebanyakan dilakukan kepada anakanak, sehingga peneliti di sini tertarik dengan penelitian yang dilakukan pada remaja.

Berdasarkan pada penjelasan di atas, tujuan dari penelitian yang dilakukan ini adalah untuk mengetahui pengaruh dari adiksi smartphone terhadap perilaku agresif pada remaja yang sekarang sering ditemui. Manfaat penelitian ini jika hasil temuan sesuai dengan hipotesis yang ada adalah dapat memberikan manfaat bagi para orang tua atau orang-orang terdekat remaja memiliki kontribusi dalam pengontrolan penggunaan smartphone terhadap remaja tersebut untuk melakukan pengontrolan penggunaan, sehingga dapat memperkecil munculnya perilaku agresif. Selain itu, diharapkan dapat melengkapi beberapa penelitian-penelitian terdahulu dengan data yang lebih akurat.

\section{Metode Penelitian}

Penelitian ini merupakan penelitian kuantitatif dengan pendekatan survei. Pengumpulan data menggunakan teknik insidental sampling, yaitu mengambil sampel secara kebetulan, setiap individu dapat menjadi sampel dalam penelitian ini apabila memenuhi kriteria dari penelitian yang dilakukan (Sugiyono, 2016). Jumlah responden sebanyak 290 orang dengan karakteristik remaja berusia minimal 15 tahun atau setara pelajar SMA dan pengguna smartphone lebih dari 5 jam dalam sehari. Alasan digunakannya remaja untuk sampel penelitian ini adalah karena urgensi pada sekitar di mana banyaknya remaja yang sudah adiksi terhadap smartphone dan berperilaku agresif.

Pengumpulan data pada penelitian ini menggunakan instrumen skala likert. Alat ukur yang digunakan untuk variabel smartphone addiction adalah skala smartphone addiction yang diadaptasi 
dari penelitian yang disusun oleh Hijrianti dan Amalia (2019) berdasarkan teori yang dikembangkan oleh Kwon, et al (2013) dengan jumlah 36 item dan reliabilitas 0.943. Sedangkan, alat ukur yang digunakan untuk variabel perilaku agresif menggunakan skala perilaku agresivitas yang disusun oleh Septiani (2018) berdasarkan teori yang dikembangkan oleh Buss dan Perry (1992) dengan jumlah sebanyak 22 item dan reliabilitas 0.779 .

Penelitian ini menggunakan prosedur dengan beberapa tahap. Pertama, tahap perencanaan penelitian, pada tahap ini peneliti melalakukan penyusunan proposal penelitian, menentukan kriteria responden, menentukan teori yang akan digunakan, menentukan instrumen dan menentukan teknik pengumpulan data dan analisa data.. Kedua, adalah tahap untuk pelaksanaan penelitian, ditahap ini peneliti akan melakukan pengumpulan data dengan menggunakan google form. Selanjutnya, pada tahap ini dilakukan analisa data dengan menggunakan program perhitungan statistik SPSS 22, dengan uji regresi linear sederhana. Ketiga, tahap pelaporan penelitian, pada tahap ini peneliti melakukan pelaporan penelitian dengan membuat laporan penelitian secara tertulis.

\section{Hasil}

Pada penelitian ini, responden yang berpartisipasi sebanyak 290 remaja yang aktif dalam penggunaan smartphone $>5$ jam dalam sehari dan berusia 15-20 tahun. Berikut ini adalah data demografis dari responden yang berpartisipasi dalam penelitian yang telah dilakukan.

Tabel 1. Data Demografis Responden Penelitian

\begin{tabular}{lcc}
\multicolumn{1}{c}{ Kategori } & Responden & Persentasi \\
\hline Lama Penggunaan Smartphone & 290 & $100 \%$ \\
$>5$ jam & & \\
Jenis Kelamin & 86 & $29.7 \%$ \\
Laki-Laki & 204 & $70.3 \%$ \\
Perempuan & & \\
Usia & 9 & $3.1 \%$ \\
15 tahun & 19 & $6.6 \%$ \\
16 tahun & 102 & $35.2 \%$ \\
17 tahun & 82 & $28.3 \%$ \\
18 tahun & 32 & $11.0 \%$ \\
19 tahun & 46 & $15.9 \%$ \\
20 tahun & & \\
\hline
\end{tabular}

Berdasarkan hasil Tabel 1, total keseluruhan responden yang berpartisipasi sebanyak 290 remaja dengan penggunaan smartphone $>5$ jam dalam sehari. Kemudian, pada hasil di atas, partisipan dalam penelitian ini yaitu 290 remaja. Jumlah responden terbanyak ada pada usia 17 tahun dengan presentase $35.2 \%$. Sedangkan, untuk responden dengan jumlah terendah ada pada usia 15 tahun dengan presentase 3.1\%. Pada tabel di atas diketahui bahwa responden dengan jenis kelamin laki-laki sebanyak 86 orang dengan presentase $29.7 \%$ dan perempuan sebanyak 204 dengan presentase $70.3 \%$. 
Uswatun Hasanah, Udi Rosida Hijrianti, dan Iswinarti

Tabel 2. Skor Smartphone Addiction dan Perilaku Agresif

\begin{tabular}{lcc}
\hline \multicolumn{1}{c}{ Variabel } & Mean & Std. Deviation \\
\hline Smartphone Addiction & 102.31 & 17.48 \\
Perilaku Agresif & 58.79 & 10.96 \\
\hline
\end{tabular}

Bersumber pada Tabel 2, variabel smartphone addiction memiliki variasi subjek sebesar 17.48 dan nilai mean sebesar 102.31 dengan skor tersebut dapat dikatakan bahwa responden memiliki smartphone addiction yang sedang dalam penggunaan smartphone. Selanjutnya, variabel perilaku agresif variasi subjek sebesar 10.96 dengan mean sebesar 58.79 di mana skor tersebut dapat dikatakan bahwa responden memiliki perilaku agresif sedang.

Tabel 3. Deskripsi Uji Regresi Smartphone Addiction terhadap Perilaku Agresif

\begin{tabular}{ccccc}
\hline $\begin{array}{c}\text { Koefisien Korelasi } \\
(\mathbf{r})\end{array}$ & $\begin{array}{c}\text { Koefisien } \\
\text { Determinasi }\left(\mathbf{R}^{2}\right)\end{array}$ & Sig & B & Kesimpulan \\
\hline 0.377 & 0.142 & 0.000 & 0.236 & Signitfikan \\
\hline
\end{tabular}

Menurut hasil pada Tabel 3, didapatkan nilai signifikansinya adalah 0.000 di mana nilai tersebut lebih kecil dari taraf signifikansi yang digunakan yaitu $0.05(P<0.05=0.000<0.05)$. Hasil penelitian tersebut menjelaskan terdapat pengaruh positif $(B=0.236)$ antara smartphone addiction terhadap perilaku agresif pada remaja, hal tersebut menunjukkan bahwa penggunaan smartphone yang berlebih hingga menyebabkan adiksi dapat memicu munculnya perilaku agresif pada remaja. Koefisien determinasi $\left(R^{2}\right)$ pada tabel di atas adalah 0.142 di mana terdapat kontribusi variabel dependent terhadap variabel independent sebesar $14.2 \%$, sedangkan $85.8 \%$ dipengaruhi oleh variabel yang lainnya diluar dari penelitian ini.

\section{Pembahasan}

Penelitian ini memiliki tujuan untuk mengetahui tentang kontribusi smartphone addiction terhadap pengaruh munculnya perilaku agresif pada remaja. Perilaku agresif dapat dilihat dari munculnya dimensi agresi. Dimensi agresi menurut Buss dan Perry ada empat, yaitu agresi fisik, agresi verbal, kemarahan dan kebencian (Palinoan, 2015). Penelitian yang dilakukan kepada 290 orang remaja pengguna smartphone aktif menghasilkan bahwa pengguna yang adiksi rata-rata berada ditingkat sedang. Sejalan dengan pendapat yang dikemukakan oleh Bae (2017) yaitu periode remaja adalah masa perkembangan otak yang lebih rentan terhadap kecanduan. Hasil penelitian ini juga menyatakan bahwa remaja dengan smartphone addiction memiliki perilaku agresif yang ratarata berada pada tingkat sedang. Hal tersebut dapat membuktikan hipotesa pada penelitian ini yang menyatakan bahwa terdapat pengaruh dari smartphone addiction terhadap perilaku agresif. Hasil penelitian yang membuktikan bahwa penggunaan smartphone yang berlebih hingga menyebabkan adiksi dapat memicu munculnya perilaku agresif pada remaja. Sehingga hal tersebut mendukung hipotesa dari penelitian ini bahwa smartphone addiction memiliki kontribusi mempengaruhi munculnya perilaku agresif pada remaja.

Hasil penelitian memperkuat dari hasil penelitian Lee, et al (2018) yang dalam penelitiannya menyatakan bahwa smartphone addiction menyebabkan beberapa masalah perilaku dan emosi, 
seperti halnya kecenderungan agresivitas dan perilaku untuk merusak diri. Hal tersebut sesuai dengan hasil penelitian yang menyebutkan bahwa adanya smartphone addiction pada remaja bisa memunculkan perilaku agresif pada remaja yang sering dilakukan. Hal tersebut juga sesuai dengan salah satu aspek pada smartphone addiction, yaitu withdrawal di mana seseorang merasa tidak sabar, resah, dan tidak tahan apabila tanpa smartphone yang dapat menyebabkan munculnya perilaku agresif seperti merengek atau berteriak karna menginginkan smartphone.

Dampak penggunaan smartphone yang berlebihan hingga adiksi pada hasil penelitian ini menunjukkan dapat memicu perilaku agresif ditingkat sedang pada remaja dan semakin sering penggunaan smartphone hingga memiliki adiksi maka makin semakin besar juga kemungkinan perilaku agresif pada remaja muncul, hal tersebut cukup mengganggu aktivitas remaja yang dalam kesehariannya yang seharusnya dapat berkomunikasi dengan baik pada orang-orang sekitarnya, namun terhambat oleh perilaku agresif yang muncul. Hal tersebut sejalan dengan penelitian Barkley dan Lepp (dalam Fauzi, Apriliyanti, Khoir \& Hamu, 2020) menyebutkan remaja yang kecanduan dengansmartphone mengalami beberapa masalah psikologis seperti perilaku agresif, harga diri rendah dan gangguan komunikasi. Selain itu, tayangan-tayangan kekerasan yang didapatkan remaja pada smartphonenya dapat memicu munculnya perilaku kekerasan. Siddiqah (2010) menyebutkan bahwa ada beberapa faktor yang dapat menyebabkan atau mempengaruhi besarnya peluang munculnya perilaku agresif, yaitu faktor biologis, adanya temperamen yang sulit, terpengaruh pada pergaulan yang negatif, mendapat pengaruh dari tayangan kekerasan dan lain sebagainya.

Smartphone addiction pada penelitian ini memiliki kontribusi sebesar $14.2 \%$ terhadap perilaku agresif, sedangkan sisanya dipengaruhi oleh faktor lain. Ada beberapa faktor lain yang dapat menyebabkan perilaku agresif di luar dari smartphone addiction pada remaja yaitu seperti sikap bawaan dan pengaruh lingkungan sebayanya, seperti pernyataan Palinoan (2015) pada penelitiannya menyebutkan bahwa perilaku agresif bentuk serangan tertentu, sifat bawaan, serta sikap kepercayaan terhadap kekerasan. Selaras juga dengan pernyataan Goldstein \& Glick (1994) menyatakan perilaku agresif yang terjadi pada remaja akan konsisten dan terjadi dengan cepat, terlebih jika mendapat dukungan dari lingkungan sebayanya, sehingga kebanyakan remaja akan memilih berperilaku agresif untuk menyelesaikan permasalahannya. Selain itu, pada penelitian yang dilakukan oleh Restu, Yusri dan Ardi (2013) menyebutkan bahwa penyebab dari perilaku agresif dari beberapa berbagai faktor, yaitu kurang diperhatikan, adanya tertekan, memiliki pergaulan yang buruk dan melihat tayangan kekerasan dimedia massa. Media massa bisa didapatkan melalui smartphone.

Faktor lain yang dapat menyebabkan perilaku agresif salah satunya dalah bermain game online. Hal tersebut sejalan dengan penelitian yang dilakukan oleh Musthafa, Ulfa, Herieningsih dan Pradekso (2015) bahwa perilaku agresif kebanyakan dipengaruhi oleh games online, perilaku agresif dapat terjadi karena karakter yang dilihat darigames online yang banyak mengandung unsur kekerasan, sehingga besar kemungkinan menimbulkan perilaku agresif lebih tinggi. Dimensi agresi yang sering terdapat pada individu yang memiliki adiksi pada games online adalah agresi verbal dan fisik. Serupa dengan penelitian Apriyanti dan Harmanto (2015) yang menyebutkan bahwa dampak permainan games online dapat menimbulkan perilaku agresif, agresi fisik dan verbal. Perilaku agresi fisik berupa adanyan interaksi fisik dalam permainan dan berdampak pada peniruan dalam kehidupan sehari-hari. Sedangkan, agresi verbal berupa kata-kata kasar dan jorok yang juga berdampak pada peniruan kehidupan sehari-hari. Hal tersebut juga diperkuat penelitian oleh Pitaloka 
(2013) dampak negatif bermain games online terus menerus yaitu malas belajar, lupa waktu, boros, berbicara dengan kasar, berperilaku agresif, pergaulan tidak dapat terkontrol dan mengganggu kesehatan fisik maupun psikis. Bermain games online berhubungan erat dengan peggunaan smartphone yang terus menerus dan menyebabkan smartphone addiction.

Keterbatasan dalam penelitian ini salah satunya peneliti tidak membahas satu persatu aspek dan dimensi dari variabel yang terkait dengan penelitian ini, hanya membahas beberapa saja. Selain itu, banyaknya faktor lain yang mempengaruhi perilaku agresif juga menjadi keterbatasan dari penelitian ini, yaitu hanya berfokus pada satu faktor penyebab perilaku agresif, sedangkan ada beberapa faktor lain yang dapat mempengaruhinya. Selain itu, keterbatasan pada penelitian ini, peneliti mengalamin kesulitan dalam menemukan jurnal yang sesuai dengan bahasan dalam penelitian ini dan sesuai dengan tema yang terkait pada penelitian ini.

\section{Kesimpulan}

Berdasarkan hasil dari analisa data dengan menggunakan uji regresi linier sederhana, diperolehhasil penelitian yang menyebutkan bahwa adanya pengaruh positif dari smartphone addiction terhadap perilaku agresif pada remaja $(B=0.236)$ dengan taraf signifikan $p=0.000$. Kemudian smartphone addiction memiliki kontribusi sebesar $14.2 \%$ terhadap perilaku agresif. Maka, dapat dijelaskan bahwa penggunaan smartphone secara berlebihan hingga menyebabkan adiksi dapat memicu munculnya perilaku agresif pada remaja. Hal ini berarti hipotesa dapat diterima dikarenakan adanya pengaruh positif dari smartphone addiction terhadap perilaku agresif pada remaja.

\section{Implikasi}

1. Implikasibagi orangtua atau orang terdekat

Implikasi bagi para orang tua atau orang-orang terdekat remaja memiliki kontribusi dalam pengontrolan penggunaan smartphone terhadap remaja tersebut. Adanya kontrol dari orang terdekat, bisa mengurangi potensi munculnya perilaku agresif pada remaja. Hasil penelitian ini dapat digunakan oleh para orang tua sebagai salah satu referensi untuk mengontrol smartphone addiction terhadap anak terutama usiaremaja untuk mengurangi perilaku agresifnya.

2. Implikasi bagi peneliti selanjutnya

Bagi para peneliti selanjutnya yang ingin melakukan penelitian ini kembali, diharapkan untuk menggunakan variabel lain untuk lebihmengembangkan hasil penelitian ini.

\section{Daftar Pustaka}

Aljomaa, S. S., Al.Qudah, M. F., Albursan, I. S., Bakhiet, S. F., \& Abduljabbar, A. S. (2016). Smartphone addiction among university students in the light of some variables. Computers in Human Behavior, 61, 155-164. doi:10.1016/j.chb.2016.03.041.

Apriyanti, M.F., \& Harmanto, H. (2015). Perilaku agresif remaja yang gemar bermain game online (studi kasus di keluarahan ngagel rejo kecamatan wonokromo surabaya). Kajian Moral dan Kewarganegaraan, 2, 994-1008.

Aziz, R., Mangestuti, R. (2006). Pengaruh kecerdasan intelektual, kecerdasan emosional, dan kecerdasan spiritual terhadap agresivitas pada mahasiswa UIN Malang. El-Qudwah: Jurnal Penelitian Integrasi Sains dan Islam, 1, 70-84. 
Bae, S.M. (2017). smartphone addiction of adolescents, not a smart choice. J. Korean Med Sci,32, 1563-1564.

Badan Pusat Statistik. (2010). Profil Kriminalitas remaja. Diperoleh tanggal 5 September 2020 dari http://www.bps.go.id.

Buss, A. H., \& Perry, M. (1992). The aggression questionnaire. Journal Of Personality And Social Psychology, 63,425-459.

Cho, H.Y., Kim, D. J., \& Park, J.W. (2017). Stress and adult smartphone addiction : mediation by selfcontrol, neuroticism, and extraversion. Stress and Helath. http://doi.org/10.1002/smi.2749.

Demirci, K., Akgönül, M., \& Akpinar, A. (2015). Relationship of smartphone use severity with sleep quality, depression, and anxiety in university students. Journal of Behavioral Addictions, 4(2), 85-92. doi:10.1556/2006.4.2015.010.

Dini, F.O., \& Indrijati, H. (2014). Hubungan antara kesepian dengan perilaku agresif pada anak didik di lembaga permasyarakatan anak blitar. Jurnal Psikologi Klinis dan Kesehatan Mental, 3, 30-36.

Fauzi, A., Apriliyanti, T.E., Khoir, M., \& Hamu, A. H. (2020). Indikasi kecanduan smartphone pada remaja di surabaya. Jurnal Ilmu Kesehatan, 8, 116-120.

Goldstein, A.P., \& Glick, B. (1994). Aggression replacement training : Curriculum and evaluation. Simulation \& Gaming, 25(1), 9-25.

Hijrianti, U.R., \& Amalia, S. (2019). Development of measurement tool of smartphone-addicted indication for middle-aged children. $4^{\text {th }}$ ASEAN Conference on Psychology Counselling, and Humanities (ACPCH-18), 304, 322-325. doi:10.2991/acpch-18.2018.78.

Hutomo, M.R., \& Ariati, J. (2017). Kecenderungan agresivitas remaja ditinjau dari jenis kelamin pada siswa SMP Di semarang. Empati, 5, 776-779.

Illahi, U., Neviyarni, N., Said, A., \& Ardi, Z. (2018). Hubungan antara kecerdasan emosi dengan perilaku agresif remaja dan implikasinya dalam bimbingan dan konseling. JRTI (Jurnal Riset Tindakan Indonesia), 3, 68-74.

INews.id. (2019). Siswa smp di Gunungkidul datangi sekolah bawa sabit ancam, guru. jateng.sindonews.com/berita/8759/1/siswa-smp-di-gunungkidul-datangi-sekolah-bawasabit-ancam-guru. Diakses 29 Januari 2020 jam 19.00 WIB.

Kwon, M., Kim, D. J., Cho, H., \& Yang, S. (2013). The smartphone addiction scale: development and validation of a short version for adolescents. PloS one, 8(12), e83558.

Kwon, M., Lee, J.Y., Won, W.Y., Park, J.W., Min, J.A., Hahn, C.,... Kim, D.J. (2013). Development and validition of a smartphone addiction scale (SAS). Plos One, 8, 1-7.

Lee, C., \& Lee, S.-J. (2017). Prevalence and predictors of smartphone addiction proneness among Korean adolescents. Children and Youth Services Review, 77, 10-17. doi:10.1016/j.childyouth.2017.04.002. 
Lee, J., Sung, M. J., Song, S. H., Lee, Y. M., Lee, J. J., Cho, S. M., ... \& Shin, Y. M. (2018). Psychological factors associated with smartphone addiction in south korean adolescents. The Journal of Early Adolescence, 38, 288-302.

Miura, P., \& Rukmini, E. (2016). Adiksi smartphone dan faktor-faktor yang memengaruhinya pada penumpang Transjakarta. Jurnal Perkotaan, 8, 1-11.

Musthafa, A. E., Ulfa, N. S., Herieningsih, S. W., \& Pradekso, T. (2015). Pengaruh intensitas bermain game online dan pengawasan orang tua terhadap perilaku agresif anak. Interaksi Online, 11. 1-13.

Palinoan, E.L. (2015). Pengaruh konformitas dengan agresivitas pada kelompok geng motor di Samarinda. Ejournal Psikologi, 4, 79-94.

Pitaloka, A.A. (2013). Perilaku konsumsi game online pada pelajar (Studi Fenomenologi tentang perilaku konsumsi game online pada pelajar di kelurahan Gemolong, kabupaten Sragen tahun 2013). Sosialitas: Jurnal Ilmiah Pend. Sos Ant, 3.

Restu, Y., Yusri, Y., \& Ardi, Z. (2013). Studi tentang perilaku agresif siswa di sekolah. Konselor, 2. 243249.

Santrock, John W. (2011). Life span development jilid 1 edisi ketigabelas. Jakarta: Erlangga.

Septiani, Y. A., \& Adiyanti, M. G. (2017). Art therapy berbasis cbt untuk menurunkan agresivitas anak korban kekerasan dalam rumah tangga (art therapy based on cbt to reduce aggressiveness of child victims of domestic violence). Jurnal Psikologi Indonesia, 12, 105-117.

Siddiqah, L. (2010). Pencegahan dan penanganan perilaku agresif remaja melalui pengelolaan amarah (anger management). Jurnal Psikologi , 50-64.

Sugiyono. (2016). Metode penelitian pendidikan pendekatan kuantitaif, kualitatif, dan R\&D. Bandung : Alfabeta.

Susantyo, B. (2018). Faktor-faktor determinan penyebab perilaku agresif remaja di permukiman kumuh di kota Bandung. Sosio Konsepsia, 6I, 1-17.

Syahadat, Y. M. (2013). Pelatihan regulasi emosi untuk menurunkan perilaku agresif pada anak. Humanitas , 19-36.

Utami, A. N. (2019). Dampak negatif adiksi penggunaan smartphone terhadap aspek-aspek akademik personal remaja. Perspektif Ilmu Pendidikan, 33, 1-14.

Wijanarko, J. (2017). Pengaruh pemakaian gadget dan perilaku anak terhadap kemampuan anak taman kanak-kanak happy holy kids jakarta. Jurnal Institut Kristen Borneo, 2, 1-40. 